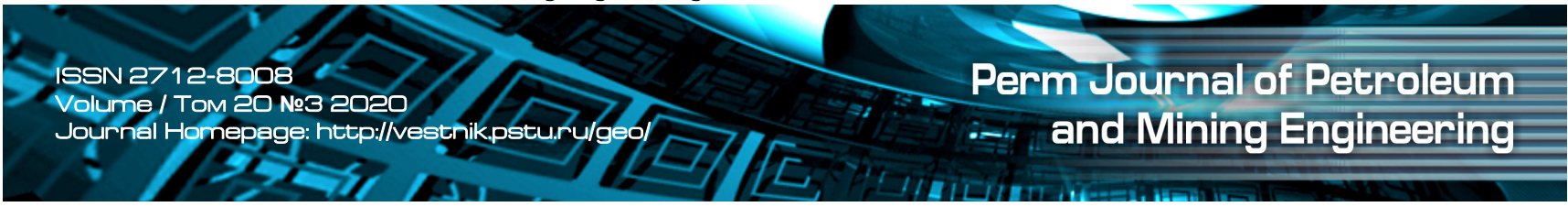

UDC 622.013.3

Article / Статья

(C) PNRPU / ПНИПУ, 2020

\title{
Analysis of Conceptual Engineering Tools in Designing Infrastructure Development Systems for Assets
}

\section{Kristina E. Kelberg, Nadezhda A. Lyadova}

PermNIPIneft branch of LUKOIL-Engineering LLC in Perm (3a Permskaya st., Perm, 614015, Russian Federation)

\section{Анализ применения инструментов концептуального инжиниринга при проектировании системы обустройства активов}

\section{К.Э. Кельберг, Н.А. Лядова}

Филиал ООО «ЛУКОЙЛ-Инжиниринг» «ПермНИПИнефть» в г. Перми (Россия, 614015, г. Пермь, ул. Пермская, 3а)

\section{Received / Получена: 03.02.2020. Accepted / Принята: 15.06.2020. Published / Опубликована: 17.08.2020}

\section{Keywords:}

conceptual design, integrated approach, infrastructure development system, asset, analysis, optimisation, map referencing, module, synergy, variability, integrated model, system engineering.
In the current macroeconomic context, it is of major importance to assess efficiency and risks of developing assets at early design stages.

Engineering design in the oil industry is currently impossible without comprehensive design technologies. Already at the initial setup stage of a facility, it is required to handle the entire package of engineering information for the whole operating cycle of such a facility. Investors have to make decisions based on incomplete and inconsistent baseline data within short timeframes.

The objectives set are addressed by using conceptual design tools.

This work is intended to assess and analyse the existing approaches to the conceptual design of the field gathering and infrastructure development system.

Presented are the methods and tools of the conceptual engineering developed by the following companies: Ingenix Group, Gazprom Neft STC (LLC), Gazprom Neft Development (LLC), RN-UfaNIPIneft (LLC), TomskNIPIneft (OJSC) and PermNIPIneft branch of LUKOIL-Engineering in Perm (LLC).

The paper presents applications of the conceptual design tools at priority facilities of the branch, including the development of the Komandirshorskaya group of fields and the feasibility study of the strategic development of the Varandey-Adzvinsky asset. For both projects, multidisciplinary teams were formed; up-to-date re-estimation of reserves and multivariate elaboration of gathering and infrastructure development system plans were performed subject to a probabilistic approach; economic feasibility was estimated and most efficient options were proposed.

Based on the analysis, the main conceptual design tools for the design of a new asset infrastructure development system were identified, and the further development options of the methods implementation at PermNIPIneft branch of LUKOIL-Engineering in Perm (LLC) were specified.

В сложившихся макроэкономических условиях очень важно на ранних этапах проектирования оценить эффективность и риски разработки актива.

В настоящее время проектирование в нефтедобывающей отрасли невозможно без реализации комплексных технологий проектирования, предусматривающих уже на начальном этапе работ управление всей технической информацией об объекте на протяжении всего цикла его дальнейшей эксплуатации. В сжатые сроки необходимо принимать инвестиционные решения, основанные на неполных и разрозненных исходных данных. Поставленные задачи решаются за счет использования инструментов концептуального проектирования.

Данная работа посвящена оценке и анализу существующих подходов концептуального проектирования системы сбора и обустройства месторождений.

Отражены методики и инструменты концептуального инжиниринга таких компаний, как Ingenix Group, ООО «Газпромнефть НТЦ», ООО «Газпромнефть-Развитие», ООО «РН-УфаНИПИнефть», ОАО «ТомскНИПИнефть» и Филиал ООО «ЛУКОЙЛ-Инжиниринг» «ПермНИПИнефть» в г. Перми.

Представлено применение инструментов концептуального проектирования на приоритетных объектах для Филиала, таких как освоение Командиршорской группы месторождений и технико-экономическая оценка разработки стратегии развития Варандей-Адзьвинского актива. По обоим проектам были созданы мультидисциплинарные группы, выполнен оперативный пересчет запасов, проведена многовариантная проработка схем систем сбора и обустройства с учетом вероятностного подхода, оценена экономическая эффективность и предложены оптимальные варианты.

На основе анализа выявлены основные инструменты концептуального проектирования для разработки системы обустройства новых активов, обозначены пути дальнейшего развития реализации методов в Филиале ООО «ЛУКОЙЛ-Инжиниринг» «ПермНИПИнефть» в г. Перми.

Kristina E. Kelberg - Chief Project Engineer at the Chief Project Engineers Department (tel.: + 007342233 76 44, e-mail: Kristina.Kelberg@pnn.lukoil.com). Nadezhda A. Lyadova (Author ID in Scopus: 36712086700) - PhD in Geological and Mineralogical Sciences, Associate Professor, Deputy General Director - Branch Director (tel.: + 00734223367 81, e-mail: nadezhda.lyadova@pnn.lukoil.com).

Кельберг Кристина Эрнстовна - главный инженер проекта отдела главных инженеров проектов (тел.: +007 3422337644 , e-mail: Kristina.Kelberg@pnn.lukoil.com). Лядова Надежда Алексеевна - кандидат геолого-минералогических наук, доцент, заместитель генерального директора - директор филиала (тел.: +007 3422336781 , e-mail: nadezhda.lyadova@pnn.lukoil.com). 


\section{Introduction}

Engineering design in the oil industry is currently impossible without comprehensive design technologies. Already at the initial setup stage of a facility, it is required to handle the entire package of engineering information for the whole operating cycle of such a facility.

The design of major fields with complex infrastructures and technical solutions involves facility clustering in functional groups (production treatment facilities, pipelines, support infrastructure, etc.) designed by experts headed by project managers and chief engineers. A review of design solutions for a set of facilities of various functional groups reveals many inconsistencies. It happens despite the fact that projects for individual facilities are developed in strict compliances with technical design specifications, requirements of applicable design standards and get approval by the Main State Expert Review Board.

Furthermore, this approach to field infrastructure developments at later design stages or during operations themselves reveals prospects of using resources of one technological system for another one, i.e. synergy and exergy effects take place, which are usually not considered during design implementations. A comprehensive concept of a field development prevents from many inefficient design choices and revisions in its design documentation [4].

The conceptual design is a project stage where applications of new technologies will be considered and their effect on the whole project feasibility will be estimated [1-16].

In this regard, it is critical to analyse tools and methods of conceptual engineering of oil and gas companies, define their main advantages, prospects and existing disadvantages.

\section{Ingenix Group}

Ingenix Group is a consulting company in the oil and gas industry, that created Ingenix Cost Manager (ICM) software for a comprehensive valuation of an oil and gas project, which allows for the integration of technical computing, map referencing and automatic calculation of lengths of linear facilities and their value.

This software enables a spatial allocation of technical data on a map, with an automated calculation of lengths of the linear facilities and their value estimation, which significantly saves valuation time and increases its accuracy.

ICM uses an integrated approach that combines the use of value models and a mapping module [17].

In the cost database, each facility features a detailed breakdown of production units and equipment, while each value is broken down by cost elements: construction and installation, equipment, etc. Such attributes provide an insight into a facility's structure and allow adjusting its value in the future, when initial technical conditions alter.

This module contains valuation tools and a mapping module: the spatial allocation of the facility on the map and the cost estimation process can run virtually concurrently. This feature allows for the following map manipulations:

- map the facilities that are already included in the project (the costs have already been estimated)

- link up the area facilities by the linear infrastructural facilities. The technical data associated with the topography will be obtained directly from the map, while the remaining parameters of the value model will be available for selection from a set of recommended values

- significantly reduce the estimation time and increase its accuracy due to the mapping module, as well as the automation of baseline data collections, reviews of multiple technical scenarios and integration with other software packages [1].

When modelling engineering linear facilities using geodata, the system uses map-derived data as input parameters (Fig. 1). The quality of map materials has a direct impact on the accuracy of linear facility value calculations [1].

Based results of geoprocessing services (obtaining geodata), technical parameters of facilities and ICM value engineering, multiple technical scenarios can be assessed. By comparing the obtained facilities, the user can choose an optimal solution.

Facilities are also compared in the software interface, including the analysis of their multilevel structure. All levels of detailing are involved in the comparison. All comparable objects can be analysed by a composition of production units and equipment.

A user selects an optimal solution based on multiple options of engineering and valuation of facilities. 


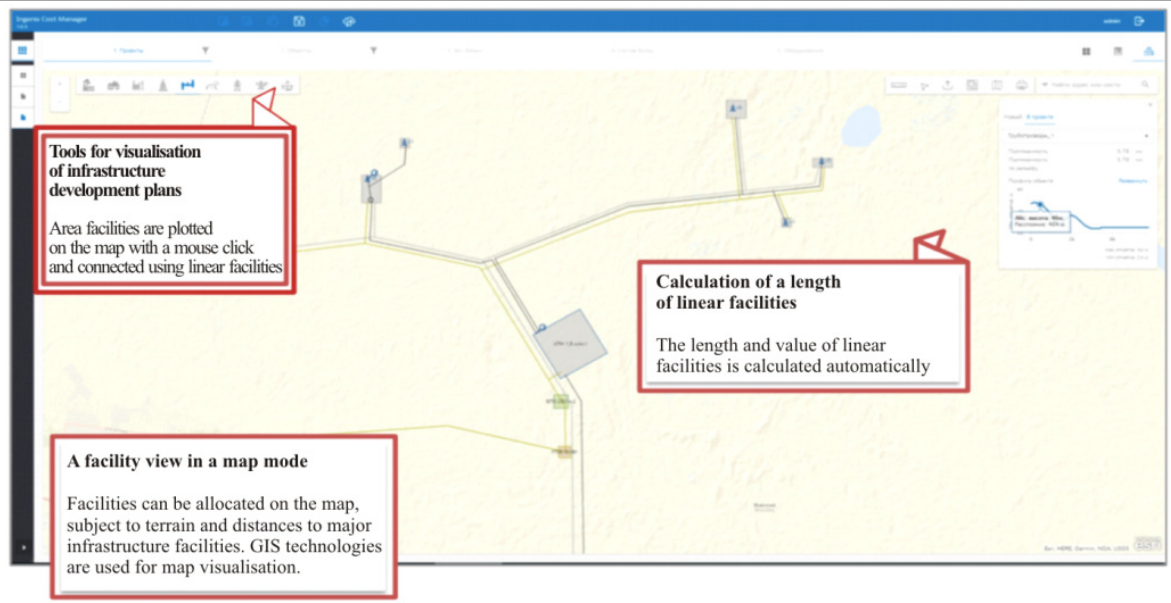

Fig. 1. ICM software suite: infrastructure development system engineering by map data

Within this solution, the technological characteristics of a facility are calculated in PIPESIM. The calculation results are sent via GIS connector to ICM, where a facility value is calculated and its composition (including equipment) is determined.

The calculation results can be used both in ICM when determining the capital and operating cost profile and a project's economic feasibility, in general, and in Schlumberger software [1].

The introduction of a comprehensive approach to the application of specialised mapping services and value models enabled the conceptual engineers to significantly reduce their workload and focus on more essential processes of engineering solution optimisations. Also, the estimation time for oil and gas project costs was reduced, while its accuracy was improved [17-23].

Advantages:

- clear user-friendly interface in Russian

- automated estimation of linear facility construction costs during geodata-based engineering

- possibility to compare multiple options in the software interface

- allowance for terrain during facility engineering and subsequent valuation.

Disadvantages:

- no import of map data of engineering surveys in various formats.

Under development:

- further integration with other software solutions and products with related functionalities.

\section{Gazprom Neft STC, \\ Gazprom Neft-Development}

To determine an optimal option of the surface infrastructure development system, subject to variability of production baseline data, the analysis approach was adjusted for probability profiles for individual sources based on the 'ERA:ISKRA' information system of the integrated conceptual design.

Step 1. Baseline data collection and import into the 'ERA: ISKRA' information system. The list of the input data is, as follows:

- source production profile options (individual well, well pad, field or licence areas) for which the probability values included in the calculation can be set

- physical and chemical properties of fluids;

- map data displayed to scale with bridging to the given coordinate system in the 'ERA:ISKRA' information system, which allows one to determine the length of linear facilities in the system

- specific indicators (for calculating capital investments and operating costs) to determine economic feasibility parameters in the financial economic model [24].

Step 2. Design of surface infrastructure development plans. The surface development plan is designed based on the map data on the location of certain development facilities and tank oil transfer stations.

Step 3. Determination of technical and economic parameters for plans depending on production options. A list of calculation instances is formed based on production profiles data and infrastructure development plan options.

For each calculation instance, based on the algorithms in the 'ERA:ISKRA' information system, performed were the calculations of profile designs of development facilities by year, hydraulic designs with pipeline diameter selections, and 
capacity of oil pumping stations and oil transfer stations. A possible commissioning date was set for each facility [24].

The 'ERA:ISKRA' information system allows for various combinations of production profiles for each source. More than three production profiles can be used for individual facilities with a high degree of subsurface uncertainty. Or, conversely, only one profile can be used for facilities with a reliable prediction. Also, a zero profile can be set for a facility, in the event of an unproven production risk or a chance of production abandonment [24-32].

The implemented approach to calculations provides for different options of production profiles depending on a production volume as well as by a commissioning date of development facilities.

Once the technical parameters are determined for each calculation instance, economic indicators are to be calculated. Hereby, the following key parameters can be determined for the regional strategy in the information system:

- capital investment in development facilities

- operating costs

- total cost of ownership (TCO)

- net present value (NPV).

Step 4. Selection of a recommended option. Based on the economic indicator values obtained, a rating of development options is generated, based on which, a development plan with the lowest average TCO is selected.

The system makes it possible to select recommended options by the following indicators:

- by cost value (total capital investment and operating costs, cost behaviour, TCO)

- by economic performance indicators: net present value (NPV), profitability index (PI), internal rate of return (IRR).

In case of close average economic indicators, a recommended option can be selected based on the maximum and minimum parameter spread or the expected departure from the average. This option allows one to identify a technical solution that is most tolerant to variable parameters and has flexible characteristics [26].

Thus, a choice of a recommended option is based not on individual input data, but rather on a successive multivariate calculation, and provides a quantitative assessment of the risk associated with an alteration in the input data on the production profile [24].

Step 5. Determining optimal parameters of the infrastructure development system. For the recommended infrastructure development option selected, technical parameters are determined in the 'ERA:ISKRA' information system for a multitude of options depending on production profiles. The next task is to determine specific technical parameters of the system (unit capacity, pipeline diameters, commissioning dates), to be used for further designing [26].

The task can be addressed by using the following options (this function is performed by the design team):

1. Based on the calculations performed, a parameter value that corresponds to the greatest number of options is selected in the system.

2. Subject to possible production options varying from the minimum to the maximum, determination of separate start-up complexes with the phased commissioning of facilities is provided for.

3. EMV and NPV economic indicators can be used for a final decision.

Advantages:

- comprehensive initial data import (production profile, map data, value indicators)

- multivariate calculations

- function of refinement by economic indicators.

Disadvantages:

- no linear facility engineering

- no provision for power supply units

- no integration with 3D module.

Under development:

- increase in the number of modules in the information system, and development of optimisation tools to compute a larger data array.

\section{Rosneft Oil Company}

Rosneft Oil Company has introduced an information and telecom system to manage oil and gas field development facilities ('ITSUP-RN'), which, in particular, ensures that the customer and design companies work in a single information space.

Intergraph SmartPlant product suite was adopted as a host software for the general functionality of 'ITSUP-RN' system, its implementation started in RN-UfaNIPIneft in 2006. [35].

SmartPlant suite is divided into the following groups by processes:

- SmartPlant 2D: design of a project's process engineering part, electrical engineering, 
instrumentation and control engineering, and onsite production facility maintenance

- SmartPlant 3D: development of the facility's 3D model, project documentation release, and onsite production facility maintenance

- SPF/TEF: Web-technology-based integration and management of all design data [36].

At the Institute, the following Intergraph software products were introduced into operation: SmartPlant P\&ID, SmartPlant Instrumentation (INTOOLS) and Smart Plant Electrical. SmartPlant 3D and SmartPlant Foundation (SPF) solutions are currently at the implementation stage (Fig. 2) [35-36].

These products are based on a single database under Oracle or MS SQL, which is particularly relevant for large arrays of information typical of industrial engineering. An up-to-date database allows one to maintain the uniqueness of names at the element level, avoid duplication of information and maintain referential data integrity at all design stages. A close integration with office applications and other programs supporting the OLE standard significantly simplifies the process of obtaining various reporting and design documentation [35-36].

Share data via the Internet is another distinguishing feature of these products, which is essential in the present context; where design projects are often carried out remotely by departments connected only by telephone lines and the Internet. This is relevant for the data transfer to remote construction sites and the elaboration of enquiry specifications by other departments based on process engineering solutions [35].

SmartPlant P\&ID software module allows us to engineer integrated intelligent process flow diagrams with installation of process equipment, pipe fittings and instrumentation.

An important feature of SmartPlant P\&ID is the equipment database integration with the schema components, i.e. the possibility of selecting a schema component by specific parameters from the existing equipment database and adding the parameters of this component (name, diameter, GOST or TU (specs), manufacturer, pressure, etc.) in the form of attribute information to the process flow diagram.

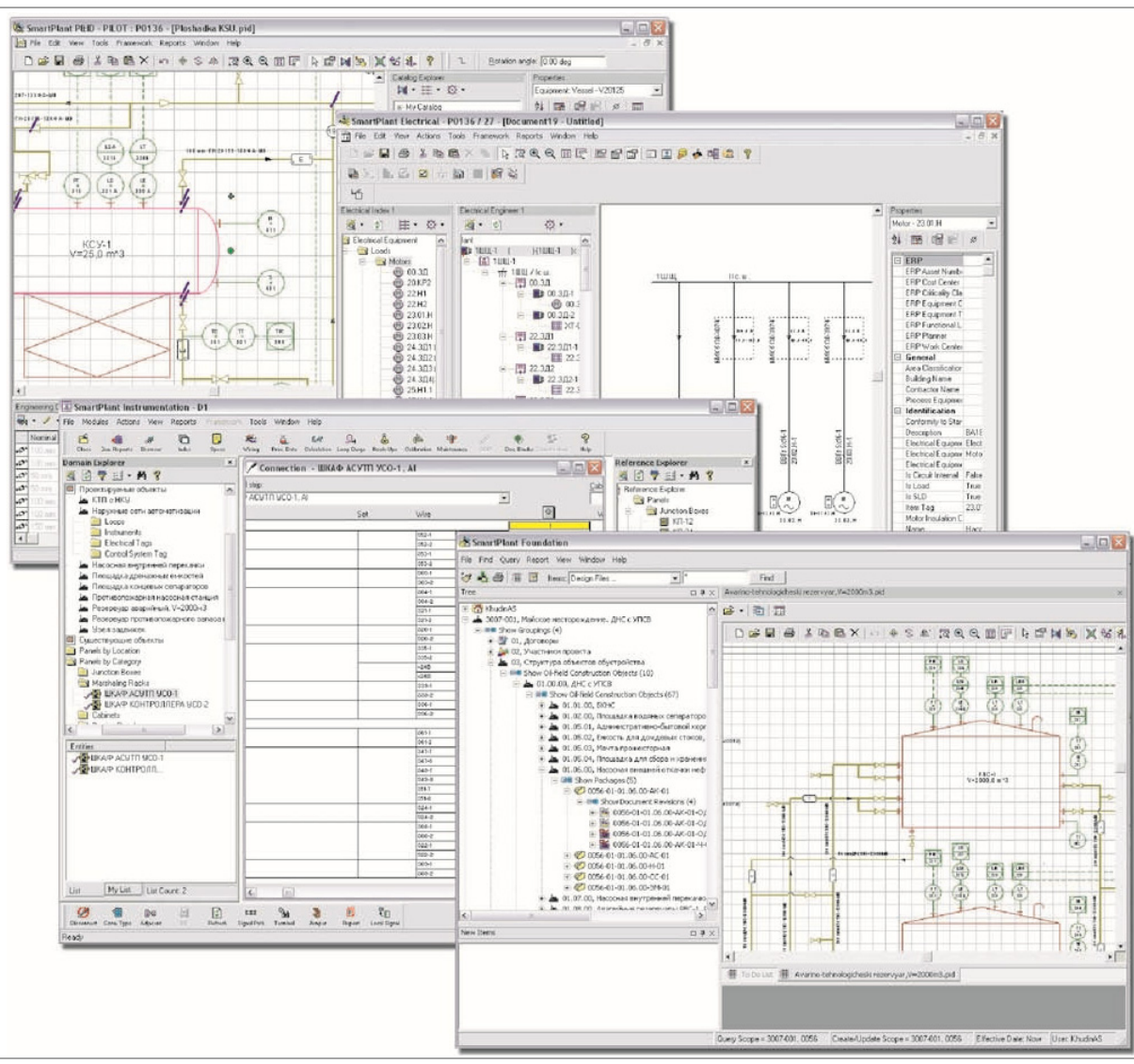

Fig. 2. Examples of designing in SmartPlant 
To further use the schema throughout the design stage, the maximum saturation with attribute information of each component is required. The implemented schema allows for an intellectual design analysis by various items: matching the diameters and types of pipelines, inlet and outlet flows, availability of necessary information on the schema components for their clear identification, etc.). The piping and instrumentation diagram (P\&ID) is built on a modular principle based on the allocation of facilities in the structure by master plan positions [35].

SmartPlant Instrumentation (Intools) is de facto a world standard for the design of automation systems, especially in oil production, transportation, refining, and petrochemical products. However, there is no operational background in the use of this software in Russian oil production industry. Specialists from the Instrumentation and Control Unit of the Design Department of RN-UfaNIPIneft had considerable work done to adapt and adjust the system to domestic standards [35].

An intuitive user interface, single data input, error exception, customisation of any documentation templates and export of various reports from the database have reduced the time required by trainees for software adaptation and mastering. Further design of automation systems is currently being performed in SmartPlant Instrumentation [35, 36].

SmartPlant Electrical is a specialised solution for the design and further maintenance of electrical distribution networks of industrial enterprises. The main function of this software package is the development of electric control circuits and electrical single-line diagrams. This module has proven to be one of the most challenging for mastering from the entire SmartPlant product line, which is due to the lack of background in the use of this software in Russia and a significant difference in the principles of electrical circuit engineering and execution of output documentation in Russia and abroad. The software was adapted to local requirements, and the instructions regulating designer work were issued.

In October 2006, RN-UfaNIPIneft started implementation of the 3D design module of SmartPlant 3D.

3D design systems have the following advantages:
- reduction of design errors due to collision detection functions

- automatic generation of output text documents

- labour input reduction due to automated release of drawings

- easy introduction of changes in design, interoperability of data of all design disciplines

- high quality and visualisation of design solutions.

SmartPlant design models are kept on the server as SQL Server databases and contain both graphical and attribute information. Such architecture speeds up the 3D data processing, enables users to track changes in the model in real-time modes, and simplifies administration of tasks. A complex equipment is engineered directly by designers and, if necessary, is entered into a shared catalogue of fragments. Later, the fragments can be used in further projects.

The new technology allows one to validate design solutions at an early stage in the model, in this case the final drawing will be insured against errors. The time required to create a 3D model of a facility is set off by its prompt adjustment and, if necessary, by alteration at the customer's request or for other reasons. The design work output (drawings: projections, sections and isometric diagrams) is generated from its completed model [35].

The transition to application of the entire SmartPlant product line in production environment is impossible without preliminary development and acceptance of design procedures under new conditions. In particular, authorisations to issue design documentation in the form of isometric, piping and instrument diagrams (P\&ID), etc., will be obtained.

The design information system in the SmartPlant Intergraph environment is based on the concept of creating and managing all technical information on the facility throughout its entire operation cycle. The corporate document management system in the SmartPlant Foundation (SPF) environment is designed to address this issue [36].

The SPF system provides automation of the following functions:

- information support to project participants

- electronic archive of executive documentation

- document management: document routing and follow-up 
- electronic archive integration with application software

- information security.

The system has been in use at RN-UfaNIPIneft since 2007. Beside the conventional electronic archive, implemented were the following procedures: Workflow procedure of paperless reconciliation of the design documentation, the redline editing mode and mark-up transfer during reconciliation, transfer of tasks among related business units [35].

Advantages:

- design of all process networks in one software

- forming of a heterogeneous group of experts and testing all modules in one pilot project at the initial stage of software introduction

- synergy of SPF module with the design of process networks in one software

- on-line data sharing function.

Disadvantages:

- No interface localisation to Russian

- No map referencing.

Development:

- Map module integration with SmartPlant 3D.

\section{TomskNIPIneft}

At TomskNIPIneft, based on a long experience of conceptual works, a methodology and the primary approaches to pre-project assessments of capital investment and operating costs were developed.
The methodology features a step-bystep design of technical solutions, analysis of capital investment and operating costs by options and further definition of technical solutions for a recommended option. Figure 3 shows an example of a consecutive design of technical solutions and a selection of an optimal option of the infrastructure development, according to the above methodology of TomskNIPIneft [37].

Furthermore, in the process of conceptualisation and experience accumulation, generated are template solutions with efficiency refinement for various aspects: pipelining, gas handling, power supply, etc. [37-39].

These templates allow one to exclude all inefficient solutions and optimise the asset conceptualisation already at the stage of a variant tree of a certain infrastructure development.

\section{Asset Development Engineering}

Advancement of the conceptualisation technology due to its complexity requires simplification and automation of the technical solution designing process for various options subject to probable changes in the baseline data. For this purpose, based on the above methodology, TomskNIPIneft has designed an original toolkit that represents a feasibility study information model ('IM-TEO') [37].

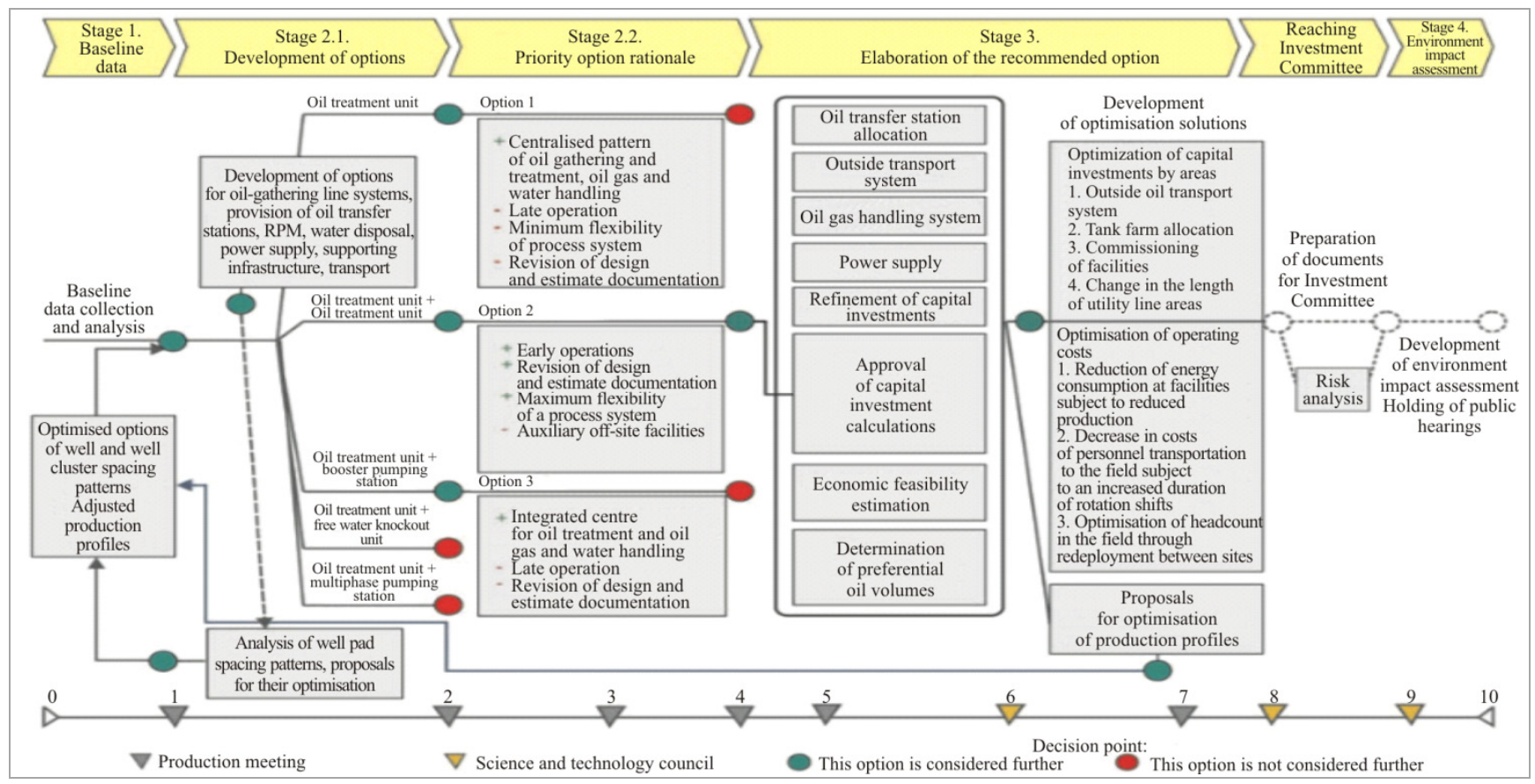

Fig. 3. Example of a conceptual design of infrastructure development using TomskNIPIneft methodology 


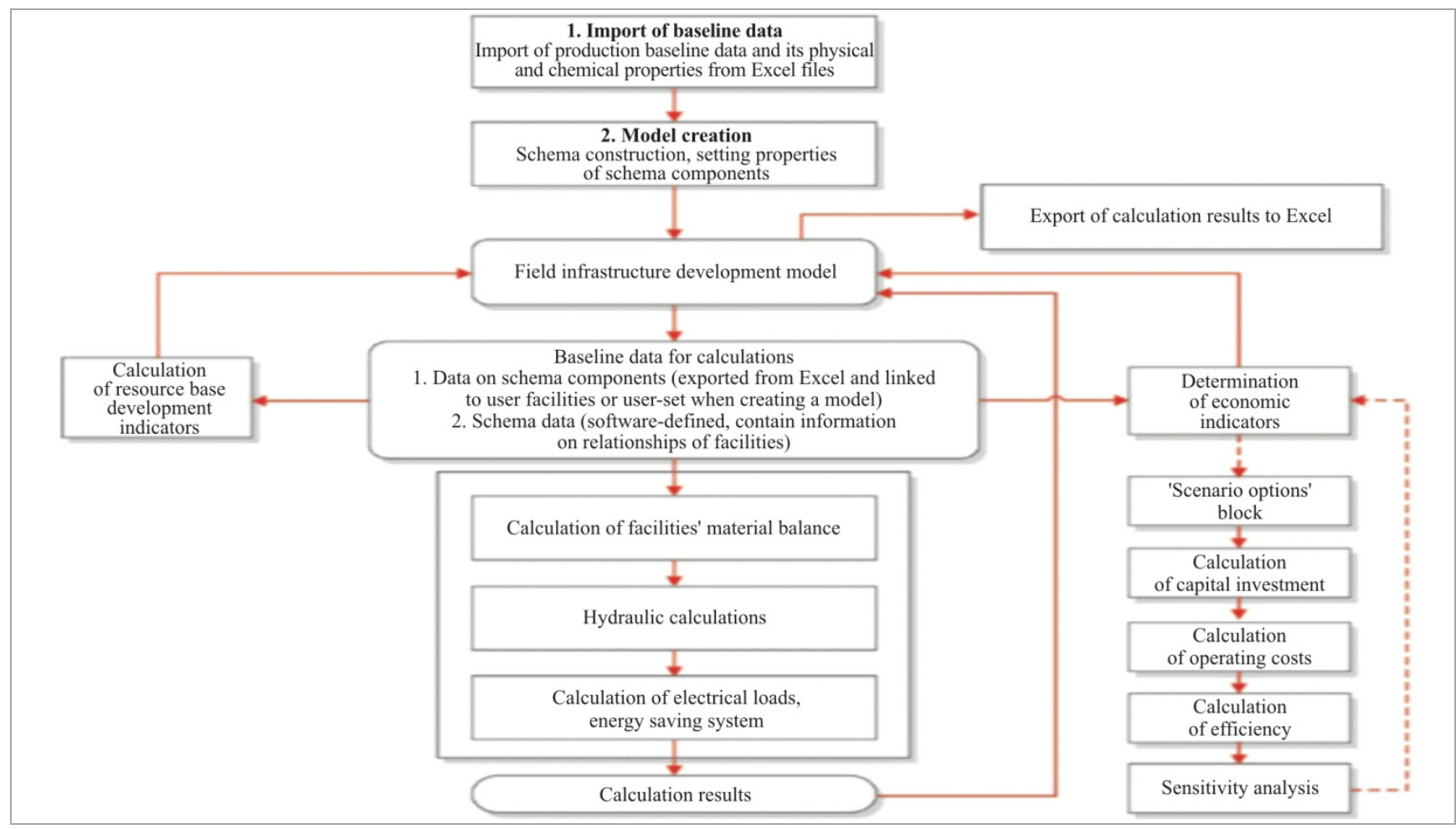

Fig. 4. IM-TEO operating algorithm

'IM-TEO' is aimed at prompt economic assessments of possible options of infrastructure surface developments of a field, groups of fields, or a region, which includes:

- input and processing of data on the production in licence areas and a licence area development sequence

- determination of key performance indicators for well drilling and well pad construction

- calculation of key performance indicators of the license area infrastructure developments

- assessment of key economic indicators based on oil and gas production data, a development sequence of licence areas and fields, drilling and infrastructure development schedule [37].

The operating algorithm of the 'IM-TEO' functional units is shown in Figure 4.

Advantages:

- approved methodology

- package import of baseline data (production profile, map data, value indicators).

Disadvantages:

- no software to synergise all calculations.

Development:

- extension of the simulation model, applicability to different regions in Russia

- integration with map databases, allowance for terrain
- development of the economic feasibility assessment multifactor module

- development of calculation modules for logistics schemes in the following areas: balance calculation of systems with oil and oil product transportation options, feasibility analysis of delivery options to the fields and selection of the least expensive option

- creation of a module that will connect underground and surface elements of the field infrastructure development.

\section{PermNIPIneft Branch of LUKOIL- Engineering LLC in Perm}

The Conceptual Engineering system is currently being introduced and implemented at PermNIPIneft branch of LUKOIL-Engineering LLC in Perm.

An operational procedure has been developed for conceptual designing at LUKOIL-Engineering for the Company's priority assets, which covers the following aspects:

- conceptual design process description

- procedure for interaction between structural units

- design preparation flow chart (Fig. 5)

- required input data list.

A comprehensive set of conceptual engineering tools is used to develop optimal systems for gathering and infrastructure development of fields: 


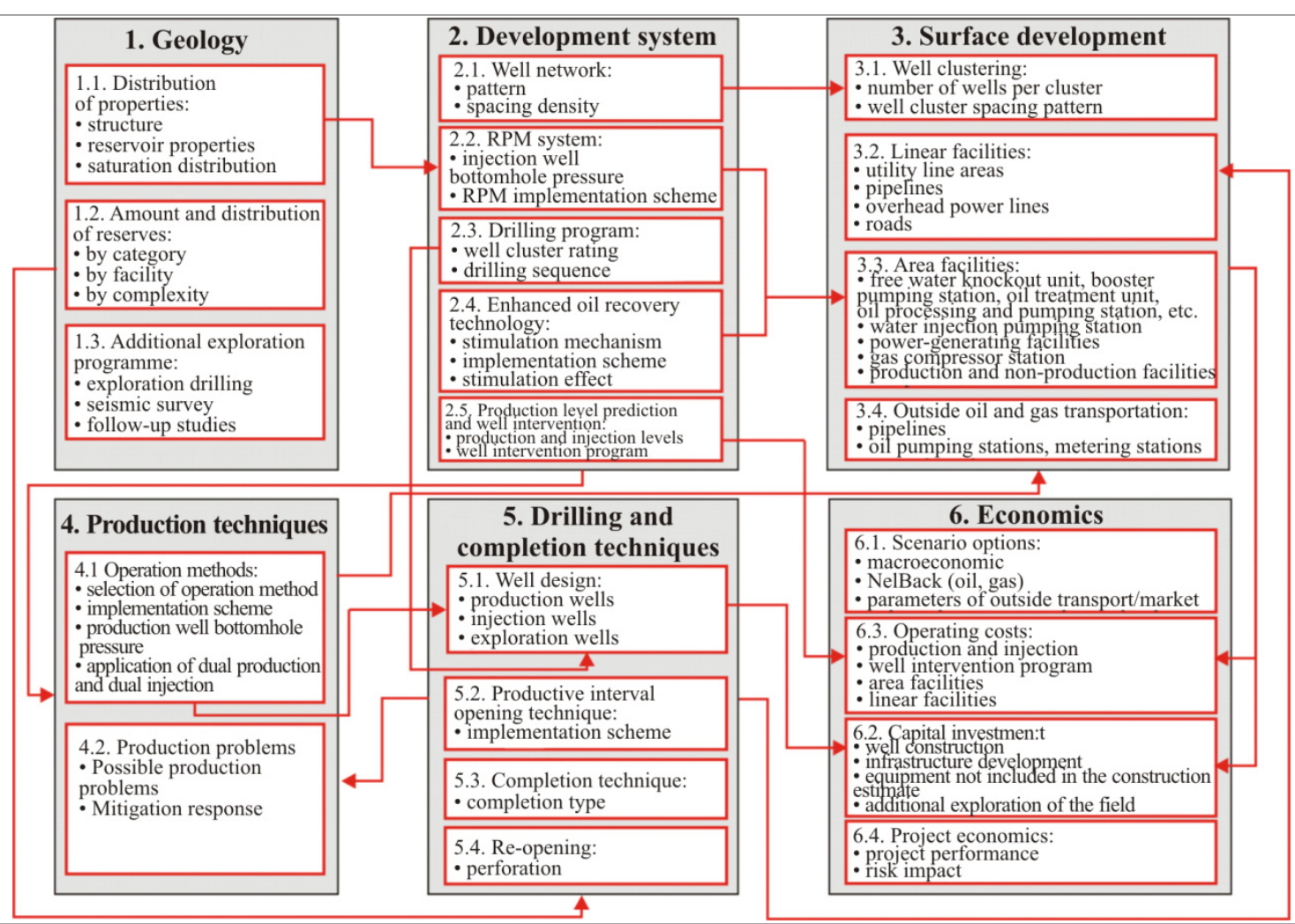

Fig. 5. Flow chart of the conceptual design preparation

- Pilot-ICE information system

- ICM 2.0

- 3D engineering of area objects

- calculation of integrated models of the field infrastructure development system.

Pilot-ICE. In 2013, Pilot-ICE information system was acquired for structuring and storing all the accumulated asset information related to design and survey works.

Initially, the information system represented a structured electronic data repository with the possibility of data import and export and a limited access function.

In 2018, the software was upgraded to eliminate hard-copy document workflow within the business unit and to strengthen control over the documentation released.

At present, the software includes a wide range of automated functions:

- data storage module: all completed projects are stored as per the design start year, including executive documentation

- task creation and issue module: it allows creating, directing and tracking all the information transferred, and ensures the logistics and structuring of documents and compliance with deadlines

- module of documentation reconciliation with the customer: the design documentation via the system folder is forwarded to the customer for approval within the software where the approval process takes place. The redline function is implemented. For each project, correspondence between a project executive and a customer's representatives using an internal chat messenger is provided for.

- The Pilot-ICE information system has significantly reduced the design documentation release workload and the amount of routine operations, which enabled the design engineers to focus on optimisation tasks and design solution upgrades.

ICM 2.0. This software is a product of Ingenix Group and an upgraded version of ICM.

Since 2015, ICM 2.0 is used for feasibility studies of priority projects and comparison of construction costs during multivariate analysis.

To adapt this software, it was required to create an in-house database based on customer's implemented projects.

ICM modules allow for the engineering of linear and area facilities based on map data at the feasibility study stage, with an option of applying cost limitations (design execution subject to limited capital investment).

3D modelling of area facilities. Application of the 3D-design tool started with the appearance of 
a 3D survey of a facility performed at the stage of comprehensive engineering surveys in 2017.

Model development is carried out by a package of software products:

- CadLib - Model and Archive: model consolidation, model structuring, administration

- ModelStudioCs - Pipelines: design of process facilities

- ModelStudioCS - Construction Solutions: engineering of reinforced-concrete and metal structures

- ModelStudioCS - Cable: design of power supply cable routes and instrumentation

- AutoDesk Civil 3D: master plan and surfaces.

To bring the software into commercial operations, the personnel training was conducted, and a working group of specialists was formed.

The application of 3D engineering has reduced the time required to release design documentation due to an automated generation of orthographic drawings.

Design engineers were enabled to enhance the quality and level of detail in the design of the facility critical components.

Since 2019, a 3D model has been applied to all area designs.

\section{Calculation of Integrated Models \\ of the Infrastructure Development System}

The integrated model is a stand-alone system of pipelines and wells.

A large amount of baseline data is required to build an informative model:

- reservoir studies

- development indicators

- geological and physical characteristics, oil and gas properties of formations, oil and gas reserves data by field, etc.

- design of production and injection wells (production string and liner with indication of setting depth, wall thickness and wall thickness change intervals)

- process flow charts of oil gathering and transportation system, reservoir pressure maintenance systems (RPM)

- a list of field pipelines (with indication of pipeline internal diameter and length), pipeline design profiles, technical inspection of pipelines

- downhole equipment data sheets

- process flow mode of production and injection wells
- information on current actual well operation parameters

The integrated model (IM) addresses the following production tasks:

- optimisation calculations for voidage replacement

- IM calculations for the period of administrative and technical activities due to a well stock shutdown, allowing to compensate for losses by increasing the flow rate of other wells for the period of administrative and technical activities

- optimisation of surface and downhole equipment

- calculations and provision of recommendations for transferring wells to RPM (stabilisation of reservoir pressure decline by formations)

- calculations and provision of recommendations for well intervention and workover.

Advantages:

- a set of engineering tools implemented

- operational procedures developed.

Disadvantages:

- no synergy of all tools in a single information space.

Development:

- approval and follow-up revision of the operational procedures

- creation of Conceptual Design functional unit

- creation of a single information space

- development of 3D-design module.

The above conceptual design tools were used at the Company's branch to develop the feasibility study for the Varandey-Adzvinskaya group and the Komandirshorskoye field.

Multidisciplinary teams were created for these priority projects, the input data flow was defined as per operational procedures, and a comprehensive assessment was performed.

\section{Development of the Komandirshorskaya Group of Fields}

To assess the development strategy of the Komandirshorskaya group of fields, oil reserves were re-calculated, with allowance for the development of new deposits.

Subject to the terms of reference, a concept for the evaluation of production potential was defined, which consisted in calculating design production levels for two resource base options: 
1) The Upper Devonian deposits of the Komandirshorskoye fields

2) The Upper Devonian deposits of the Komandirshorskoye fields with the addition of the Middle Devonian prospective deposits and the two areas: Severo-Mishvanskoye and Simbeyskoye.

Predictive levels were assessed using corresponding success probabilities: P90 Base: the highest probability of production potential for the Upper Devonian deposits of the Komandirshorskoye fields; P50 Development: a $50 \%$ probability for the Upper Devonian and Middle Devonian deposits of the Komandirshorskoye fields and the two areas: the Severo-Mishvanskoye and Simbeyskoye fields, with the application of $K_{\text {prov }}=0.423$ of the production profile to the prospective Middle Devonian deposits and the aforementioned areas; the lowest probability of success P10 Development OPTION: with maximum production levels and a set of facilities similar to option P50, but no $K_{\text {prov }}$ of the production profile was applied.

Performance indicators were determined subject to each probability, and production graphs were plotted (Fig. 6, a).

For the production levels obtained, a multivariate assessment of the development of the oil and gas gathering, treatment, transportation, reservoir pressure maintenance and power supply system was made subject to the existing infrastructure and resource base (Fig. 7).

In accordance with the baseline data, a flow chart of possible options for oil gathering, treatment and transportation was developed (Fig. 8). Based on the available specific indicators, the design capacity was calculated and economic indicators were determined in ICM 2.0 for each option (Fig. 6, b).

Further to the infrastructure development system, the RPM system and power supply options were elaborated, and the final option was determined based on the resource base for the construction and installation operations, subject to geographical features of a construction area.

Based on the feasibility study results, a positive economic feasibility option was determined including the oil treatment unit construction at the production levels of P10, P50 and $\mathrm{P} 90$.

Well fluid gathering, treatment and transportation: gathering and transportation of well fluid at Komandirshor oil treatment unit with a subsequent transportation to Kharyaga terminal (tie-in to 'Yuzhno-ShapkinskoyeKharyaga' main pipeline)

RPM system: in the initial period (until 2029), a supply of formation water from the booster pumping station to the sump pumping station with a subsequent pumping into the disposal well; after 2029, centralised pumping from the modular compressor pumping station to nearby well clusters within $5-8 \mathrm{~km}$, the excess liquid is pumped to disposal wells, local pumping in remote well clusters is performed using the pattern 'high-pressure electric centrifugal pump in a water well - pumping to injection wells in a well cluster.

Gas processing and transportation system: gas from Komandirshor oil treatment unit is pipelined to gas pipeline 'Central gathering station 'YuzhnoShapkinskoye - KS-6', to KS-6 gas compressor station or to central gathering station 'Yuzhno-Shapkinskoye' for power generation at the existing power unit.

Power supply source in operating and emergency modes is the existing 110/35/6 kW substation ' $V$. Lambeyshorskaya', with the construction of a $50 \mathrm{~km}$ long $35 \mathrm{~kW}$ overhead power line to the $35 / 10 \mathrm{~kW}$ receiving step-down substation 'Komandirshor'.

The project is currently in Phase 2 'Selection', and an interdisciplinary team is being created to further develop the design solutions.

\section{Feasibility Study of the Varandey- Adzvinskaya Group of Fields}

In 2019, a feasibility study of the VarandeyAdzvinsky asset development strategy was conducted. Up-to-date re-estimation of reserves was performed and production level options were proposed subject to implementation probability.

The multidisciplinary team has developed an optimal infrastructure development system flow chart (Fig. 9, a) and outside transportation options (Fig. 9, b).

The outside production transportation options were elaborated subject to GSM module in ICM 2.0 (allocation of facilities on a map material and estimation of capital investment). The main options were determined and the risks associated therewith were identified:

- The need to obtain consent from third-party subsoil users (Rosneft Oil Company (PJSC), Bashneft-Polyus (Joint Venture)) for land development within claim areas and permission from the Russian Federation Federal Agency for Mineral Resources for development of land plots 


\begin{tabular}{|c|c|c|}
\hline Field & $\begin{array}{l}\text { Reserves (original oil } \\
\text { in place/initial recoverable } \\
\text { reserves), thous, tons }\end{array}$ & $\begin{array}{l}\text { Cumulative production } \\
(2020-2049) \text {, thous. tons }\end{array}$ \\
\hline Komandirshorskoye & $4025 / 1216$ & 1130 \\
\hline Severo-Komandirshorskoye & $5938 / 2197$ & 1532 \\
\hline Zapadno-Komandirshorskoye & $7929 / 2934$ & 2311 \\
\hline Total & $17892 / 6347$ & 4973 \\
\hline Field & $\begin{array}{l}\text { Reserves (original oil } \\
\text { in place/initial recoverable } \\
\text { reserves), thous. tons }\end{array}$ & $\begin{array}{l}\text { Cumulative production } \\
\text { (2020-2049), thous. tons }\end{array}$ \\
\hline Komandirshorskoye & $15436 / 4639$ & 2419 \\
\hline Severo-Komandirshorskoye & $7540 / 2678$ & 1724 \\
\hline Zapadno-Komandirshorskoye & $15877 / 5319$ & 3321 \\
\hline Total & $38853 / 12636$ & 7464 \\
\hline Field & $\begin{array}{l}\text { Reserves (original oil } \\
\text { in place/initial recoverable } \\
\text { reserves), thous. tons }\end{array}$ & $\begin{array}{l}\text { Cumulative production } \\
(2020-2049) \text {, thous. tons }\end{array}$ \\
\hline Komandirshorskoye & $15436 / 4639$ & 3708 \\
\hline Severo-Komandirshorskoye & $7540 / 2678$ & 1917 \\
\hline Zapadno-Komandirshorskoye & $15877 / 5319$ & 4330 \\
\hline Total & $38853 / 12636$ & 9955 \\
\hline
\end{tabular}

лукойл
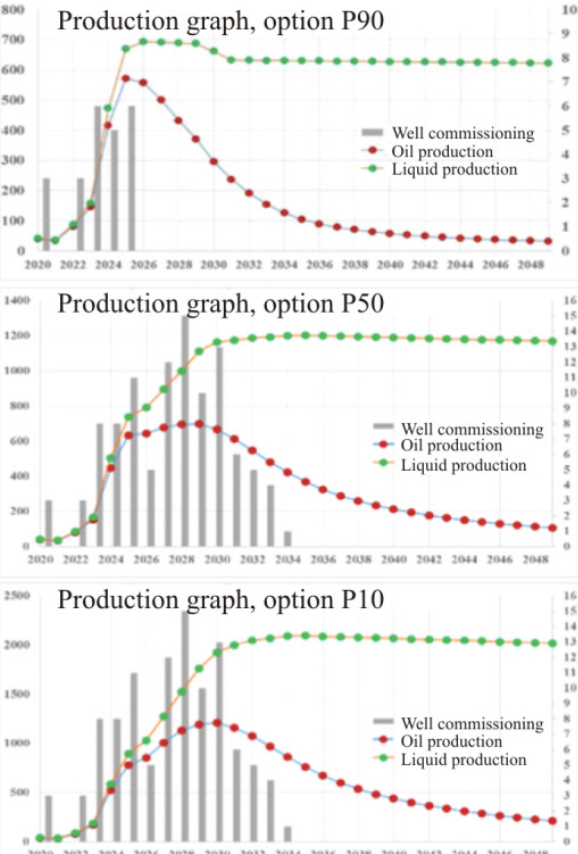

\begin{tabular}{|c|c|c|c|c|}
\hline \multirow{3}{*}{ Indicators } & \multirow{3}{*}{ UOM } & \multicolumn{3}{|c|}{ Group of fields } \\
\hline & & \multicolumn{3}{|c|}{ with oil treatment unit construction } \\
\hline & & P10 & P50 & P90 \\
\hline 1 & 2 & 3 & 4 & 5 \\
\hline Liquid production & thous. tons & 27523 & 22165 & 16806 \\
\hline Hydrocarbon production, total & thous. tons & 11803 & 8812 & 5832 \\
\hline Operating costs & mln. RUB & 56107 & 52715 & 36032 \\
\hline Investment costs & mln. RUB & 64667 & 59644 & 38514 \\
\hline Net present value & mln. USD & 128,0 & 94,0 & 89,5 \\
\hline
\end{tabular}

$b$

Fig. 6. Indicators: $a$ - performance, production graphs for options P90, P50 and P10; $b$ - economic feasibility

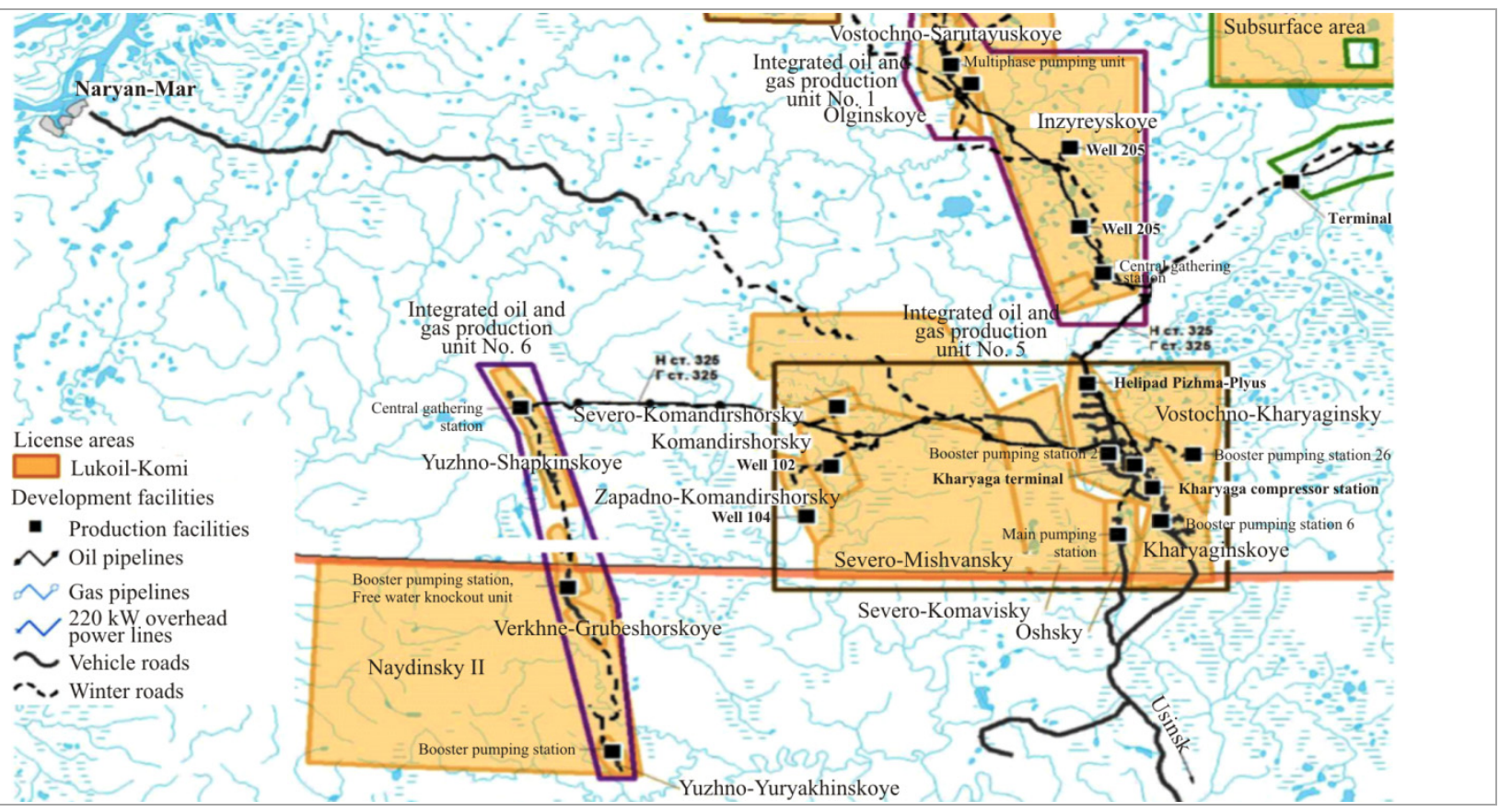

Fig. 7. Existing infrastructure 


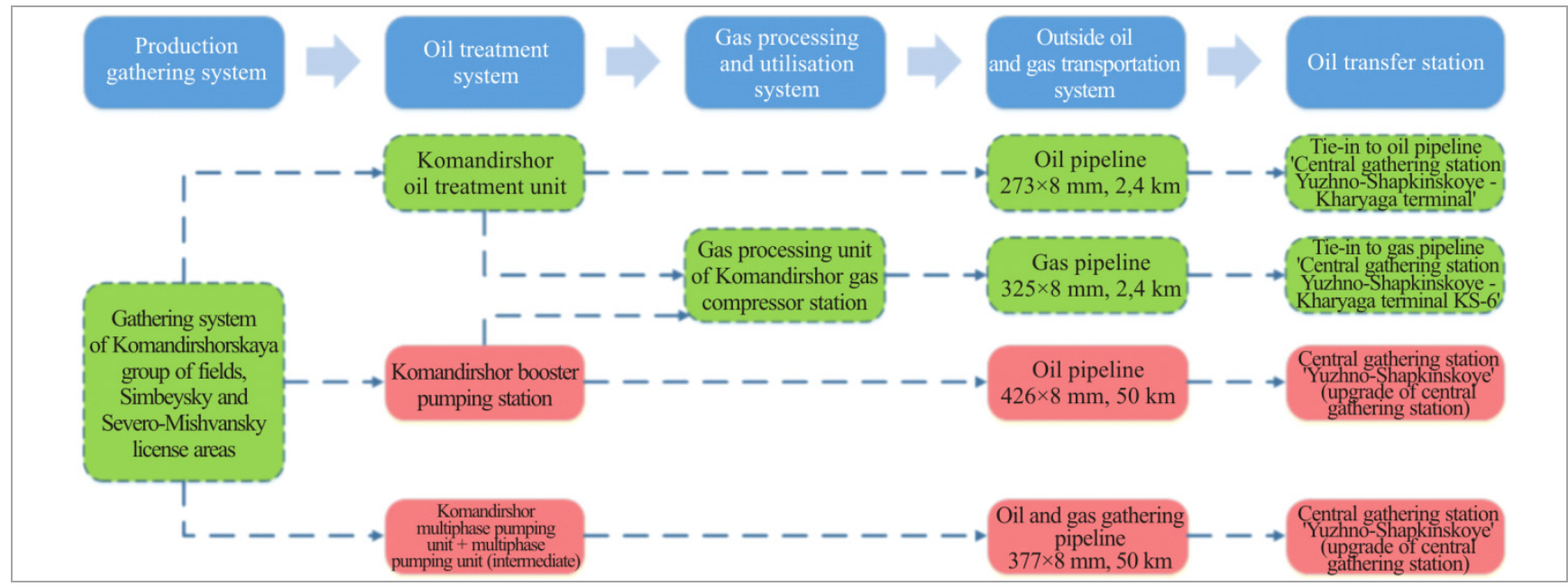

Fig. 8. Oil gathering, treatment and transportation options

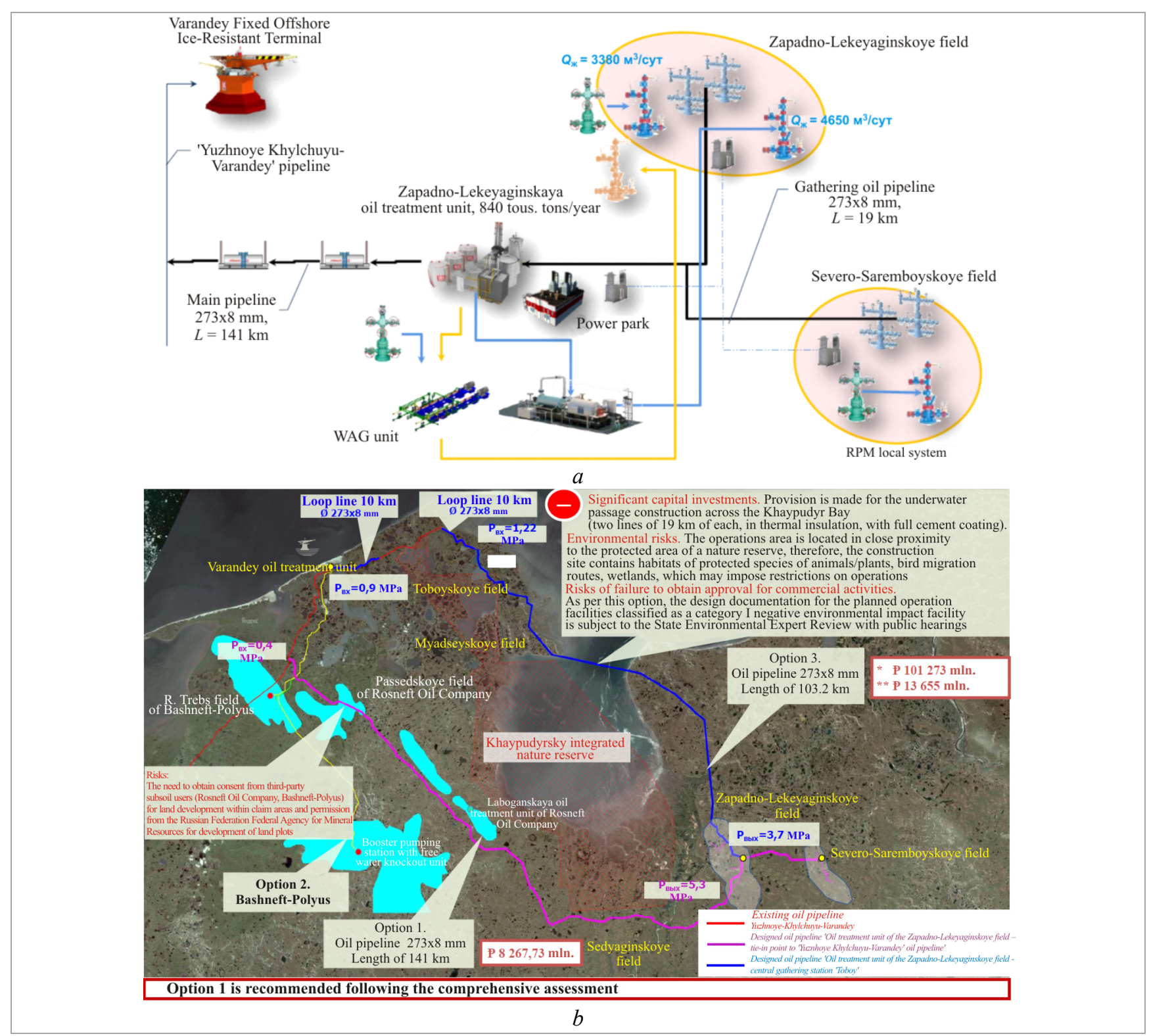

Fig. 9. Development strategy for the Varandey-Adzvinsky asset: $a$ - optimal infrastructure development flow plan; $b$ - outside oil transportation options 
Ranking of conceptual design software by leading oil and gas companies

\begin{tabular}{|c|c|c|c|c|c|c|}
\hline Software & Procedure & $\begin{array}{c}\text { Information space / } \\
\text { Software }\end{array}$ & $\begin{array}{c}\text { Conceptual / } \\
\text { Integrated model }\end{array}$ & $\begin{array}{l}\text { Map referencing } \\
\text { module }\end{array}$ & $\begin{array}{c}\text { Developme } \\
\mathrm{nt}\end{array}$ & Total \\
\hline Ingenix Group & 0.6 & 0.8 & 0.6 & 1.0 & 1.0 & 4.0 \\
\hline $\begin{array}{l}\text { Gazpromneft STC } \\
\text { Gazpromneft-Development }\end{array}$ & 1.0 & 1.0 & 1.0 & 0.8 & 1.0 & 4.8 \\
\hline RN-UfaNIPIneft & 1.0 & 1.0 & 0.8 & 0.4 & 1.0 & 4.2 \\
\hline TomskNIPIneft & 1 & 0 & 0.8 & 0 & 1.0 & 2.8 \\
\hline $\begin{array}{l}\text { PermNIPIneft branch of LUKOIL- } \\
\text { Engineering LLC in Perm }\end{array}$ & 0.5 & 0.3 & 0.8 & 0.5 & 1.0 & 3.1 \\
\hline
\end{tabular}

- since operations area is located in close proximity to the protected area of a nature reserve, therefore, the construction site contains habitats of protected species of animals/plants, bird migration routes, wetlands, which may impose restrictions on the operations

- design documentation for the planned operations facilities classified as a category I negative environmental impact facility is subject to the State Environmental Expert Review with public hearings. Based on the comprehensive assessment results, subject to the development cost and risks, option 1 was selected (installation of oil pipeline 'Oil treatment unit No. 3 of the Zapadno-Lekeyaginskoye field - tie-in point to 'Yuzhnoye-Khylchuyu-Varandey' oil pipeline', $\emptyset 273 \times 8 \mathrm{~mm}$, length of $141 \mathrm{~km}$ ). This project has no positive economic effect to date due to large capital investments.

Currently, the design team is elaborating the options to realise this asset with a sequence of phased development of the fields. The SeveroSaremboyskoye field is considered the first one to be put into production, subject to development of oil treatment facilities and linear structures, while the Zapadno-Lekeyaginskoye field is the next one to be put on line.

\section{Analysis of Applied Conceptual Design Tools}

To systematise the above analysis of the conceptual approach application to designing, the data are organised into a table with a scoring system, where values are taken from 0 to 1 depending on the extent of elaboration and implementation of the tools used (see Table).

Analysis of the table data shows that the strategy of Gazprom Neft STC appears the most successful one, as they are developing the conceptual engineering in a systematic way and expand information in a single space in compliance with internal regulatory documents.

At present, PermNIPIneft branch of LUKOILEngineering LLC in Perm, is finalising the operating procedures for input data provision from all specific units. At the next stage, contractors will be selected to develop individual modules and combine them into the WellInfo common information space.

This space allows developing conceptual models for both new and existing assets, which will enable optimisation decisions on the design and upgrade of the infrastructure development system and the maintenance of production levels.

Concurrently with the information space development, subject to the feasibility study design experience for priority facilities, multidisciplinary teams will be formed for the design of both existing and new assets based on system engineering methods [40-45].

\section{Conclusions}

In the current macroeconomic environment, it is crucial to assess the effectiveness and risks of asset developments at an early stage of design.

Presently, all major oil and gas companies use the full range of conceptual engineering tools to address this issue.

The application of comprehensive design approaches not only increases the assessment accuracy and correlates it with actual conditions, but also automates a wide range of routine tasks, which increases the time required for conceptual engineers to develop design solutions.

The development of methods and procedures ensures typification of approaches and allows creating template solutions to design tasks.

It should be noted, however, that most of the tools are related to the implementation of new assets, while no generally accepted methods for developing and maintaining existing fields have been created.

Such progress is vital since newly commissioned fields are often a part of an existing asset infrastructure development system with a range of extreme performance parameters, that is why the commissioning of 
new facilities can completely shutdown the system and oil production.

To develop the conceptual design strategy, funding shall be provided for acquisition of various software products, along with allocation of human resources and time budgeting.

Only a well-trained team of specialists in various fields is capable to comprehensively address the technological tasks.

The experience gained in the feasibility study development for the Varandey-Adzvinskaya group and the Komandirshorskoye field allows determining further developments of the conceptual design strategy at the Company's branch, the set and accuracy of the necessary baseline information, and the principles of forming a multidisciplinary team of experts. The application of conceptual design tools enables the asset development evaluation within a short period of time and optimal options obtained based on a comprehensive assessment of all factors.

\section{References}

1. Bazyleva N.Z., Panov R.A., Mozhchil' A.F., Volod'kin M.S., Bogachev I.A., Shurupov N.D. Robastnyı̌ podkhod k logisticheskomu inzhiniringu na etapakh kontseptual'nogo proektirovaniia [Robust approach for conceptual and logistic engineering integration]. Neftianoe khoziaistvo, 2019, no. 1, pp. 104-108. DOI: 10.24887/0028-2448-2019-1-104-108

2. Vlasov A.I., Mozhchil A.F. Obzor tekhnologiǐ: ot tsifrovogo $\mathrm{k}$ intellektual'nomu mestorozhdeniiu [Technology overview: from digital to intelligent field]. PROneft', 2018, no. 3 (9), pp. 68-74. DOI: $10.24887 / 2587-7399-2018-3-68-74$

3. Karsakov V.A., Tret'iakov S.V., Deviat'iarov S.S., Pasynkov A.G. Optimizatsiia kapital'nykh vlozheniı̌ v stroitel'stvo skvazhin pri kontseptual'nom proektirovanii razrabotki mestorozhdeniř [Drilling cost optimization during

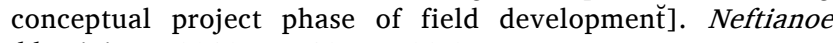
khoziaistvo, 2013, no. 12, pp. 33-35.

4. Khasanov M.M., Sugaipov D.A., Zhagrin A.V. et al. Povyshenie tochnosti otsenki kapital'nykh vlozheniı̌ na rannikh stadiiakh realizatsii proektov [Improvement of capex estimation accuracy during early project stages]. Neftianoe khoziaistvo, 2014, no. 12, pp. 22-27.

5. Abramova N.S. Neopredelennost' i risk v investitsionnom proektirovanii [Uncertainty and risk in investment planning]. Ekonomicheskie nauki, 2012, no. 1, pp. 139-144.

6. Borisova D., Sokolov S. Povyshenie otdachi ot krupnykh investitsionnykh proektov [Increasing returns on large investment projects]. Vestnik McKinsey, 2013, no. 28, pp. 6-27.

7. Ansoff I. Strategicheskiı̌ menedzhment [Strategic
[ management]. Saint Petersburg: Piter, 2011.

8. Kudriashov S.I., Belkina E.Iu., Ismagilov A.F. et al. Monitoring stoimosti stroitel'stva ob"ektov obustroĭstva mestorozhdeniĭ na razlichnykh stadiiakh investitsionnogo tsikla [Cost monitoring in oilfield construction at different stages of the investment cycle]. Neftianoe khoziaistvo, 2015, no. 11, pp. 72-75.

9. Vosstanie mashiny. Pochemu Boeing 737 MAX ubivaet liuder. 21.03.2019 [Rise of the machine. Why the Boeing 737 MAX is killing people. 03/21/2019], available at: https://ria.ru/ 20190321/1551968367.html (accessed 10 February 2020).
10. Kitroeff N., Gelles D., Nicas J. et al. After 2 Crashes of New Boeing Jet, Pilot Training Now a Focus, The New York Times, available at: https://www.nytimes. com/2019/03/16/business/ boeing-max-flight-simulator-et-hiopia-lion-air.html (accessed 07 February 2020).

11. Hubble_Space_Telescope, available at: https://www. sebokwiki.org/wiki (accessed 07 February 2020).

12. Batovrin V. Sovremennaia sistemnaia inzheneriia i ee rol' v upravlenii proektami (chast' 1) [Modern systems engineering and its role in project management (part 1)] Upravlenie proektami i programmami, 2015, no. 03 (43), pp. 166-178.

13. Kosiakov A., Svit U.N., Seĭmur S.D., Bimer S.M. Sistemnaia inzheneriia. Printsipy i praktika [Systems Engineering. Principles and practice]. Moscow: DMK Press, 2014, 624 p.

14. Kostenko K., Brezgulevskiǔ E., Miroshnichenko E. Kompetentsii sistemnogo inzhenera [System Engineer Competencies]. Molodezh' $i$ sovremennye informatsionnye tekhnologii. Sbornik trudov XIII Mezhdunarodnoi nauchnoprakticheskoi konferentsii studentov, aspirantov $i$ molodykh uchenykh. Tomsk, 2016, 515 p.

15. Porter M. Konkurentnoe preimushchestvo: kak dostich' vysokogo rezul'tata i obespechit' ego ustoĭchivost' [Competitive advantage: how to achieve high results and ensure its sustainability]. Moscow: Al'pina Biznes Buks, 2005, 716 p.

16. Bellout M.C., Echeverría Ciaurri D., Durlofsky L.J. et al. Joint optimization of oil well placement and controls. Computational Geosciences, 2012, no. 16 (4), pp. 1061-1079.

17. Iunusov I.E. Primenenie GIS-konnektora dlia kontseptual'nogo inzhiniringa i stoimostnogo modelirovaniia obustroǐstva neftegazovykh mestorozhdeniř [Application of Well Log Data Connector for Conceptual Engineering and Value Engineering for Oil and Gas Field Construction]. Neft'. Gaz. Novatsii, 2019, no. 9, pp. 51-53.

18. Khasanov M.M., Maksimov Iu.V., Skudar' O.O. et al. Stoimostnoi inzhiniring v PAO «GAZPROM NEFT"»: tekushchaia situatsiia i perspektivy razvitiia [Cost engineering in Gazprom Neft PJSC: current situation and future development]. Neftianoe khoziaistvo, 2015, no. 12, pp. 30-33.

19. Chizhikov S.V., Dubovitskaia E.A., Tkachenko M.A. Stoimostnoe modelirovanie: instrument ucheta izmeneniǐ [Costs modeling: support point in a changing world]. Neftianoe khoziaistvo, october 2017, no. 10. pp. 64-68. DOI: 10.24887/0028-2448-2017-10-64-68

20. Dubovitskaia E.A., Pashchenko A.D., Chizhikov S.V. Problemy otsenki zatrat na stroitel'stvo neftegazovykh ob"ektov v Rossii i puti ikh resheniia [Problems and proposed solutions for oil and gas projects cost estimation in Russia]. Neftianoe khoziaistvo, 2013, no. 9, pp. 92-95.

21. Bozieva I.A., Zinnatullin D.F. Aspekty sozdaniia korporativnoi informatsionnoi sistemy formirovaniia stoimosti ob"ektov stroitel'stva i obustroistva mestorozhdenii [Aspects of corporate information system development to generate the costs of construction facilities and oil and gas fields infrastructure development]. Neftianoe khoziaistvo, 2016, no. 2, pp. 114-117.

22. Chizhikov S.V., Dubovitskaia E.A. Novyi podkhod k otsenke i upravleniiu stoimost'iu neftegazovykh proektov [A new approach to the assessment and management of oil and gas projects cost]. Neftianoe khoziaistvo, 2012, no. 9, pp. 98-101.

23. Atnagulov A.R., Rakhmangulov R.D., Vinogradov P.V. et al. Opyt realizatsii bazy kapital'nykh vlozhenii po ob"ektam stroitel'stva nazemnoi infrastruktury neftianykh mestorozhdenii $\mathrm{v}$ PAO ANK "Bashneft'" [Developing capex database for oil field surface facilities construction at Bash-neft PJSOC]. Neftianoe khoziaistvo, 2015, no. 8, pp. 98-101.

24. Khamidullin R.D., Ismagilov R.R., Kan A.V., Maksimov Iu.V., Mozhchil' A.F., Dmitriev D.E., Koptelov A.S., Kondakov D.E. Vybor strategii razvitiia regional'noľ infrastruktury $\mathrm{v}$ usloviiakh neopredelennosti dobychi $\mathrm{s}$ ispol'zovaniem programmnogo obespecheniia "ERA:ISKRA" [Choosing a strategy for the development of regional infrastructure in conditions of production uncertainty 
using the ERA: ISKRA software]. Neftianoe khoziaistvo, 2017, no. 12, pp. 64-67. DOI: 10.24887/0028-2448-2017-12-64-67

25. Technical Report: Guidance for Decision Quality for Multicompany Up-stream Projects. SPE 181246, 2016.

26. Ismagilov R.R., Maksimov Iu.V., Ushmaev O.S. et al. Integrirovannaia model' dlia kompleksnogo upravleniia razrabotkoŭ i obustroisstvom mestorozhdeniı̌ [Integrated model for complex management of reservoir engineering and field construction]. Neftianoe khoziaistvo, 2014, no. 12, pp. 71-73.

27. Ismagilov R.R., Panov R.A., Gil'mutdinova N.Z. et al. Ekonomiko-matematicheskoe reshenie dlia postroeniia optimal'nor konfiguratsii lineĭnykh sistem neftegazovykh mestorozhdeniı̆ [Economic-mathematical modelling of optimal pipeline configuration]. Neftianoe khoziaistvo, 2015, no. 12, pp. 60-63.

28. Tretiakov S.V., Dmitriev D.E., Gil'mutdinova N.Z. et al. Tekhniko-ekonomicheskaia optimizatsiia kustovaniia skvazhin pri integrirovannom kontseptual'nom proektirovanii [The integrated conceptual design as a tool of systematic engineering]. Neftianoe khoziaistvo, 2016, no. 04, pp. 126-129.

29. Batrashkin V.P., Ismagilov R.R., Panov R.A. et al. Integrirovannoe kontseptual'noe proektirovanie kak instrument sistemnogo inzhiniringa [The integrated conceptual design as a tool of systematic engineering]. Neftianoe khoziaistvo, 2016, no. 12 , pp. $80-83$.

30. Alekseev A. Umnoe uskorenie [Smart acceleration]. Sibirskaia neft', 2017, no. 6/143, pp. 22-27.

31. Ismagilov R.R., Panov R.A., Mozhchil' A.F., Gil'mutdinova N.Z., Shurupov N.D., Bogachev I.A. Integratsiia kontseptual'nogo logisticheskogo inzhiniringa [Integration of logistics and conceptual design theses]. PRONeft', 2018, no. 4, pp. 60-63. DOI: $10.24887 / 2587-7399-2018-4-60-63$

32. Amorin R., Broni-Bediako E. Application of minimum curvature method to wellpath calculations. Research Journal of Applied Sciences, Engineering and Technology, 2010, no. 2 (7), pp. $679-686$.

33. Fletcher R., Leyffer S. Nonlinear programming without a penalty function. Mathematical Programming, 2002, no. 91 (2), pp. 239-269. DOI: 10.1007/s101070100244

34. Echeverría Ciaurri D., Isebor O.J., Durlofsky L.J. Application of derivative-free methodologies to generally constrained oil production optimisation problems. International Journal of Mathematical Modelling and Numerical Optimisation, 2011, no. 2 (2), pp. 134-161. DOI: $10.1016 /$ j.procs.2010.04.145

35. Iumashev E.R., Khusnutdinova K.R., Napol'skii A.A., Khudin A.S. Kompleksnaia avtomatizatsiia proektirovaniia ob"ektov obustroistva neftianykh i gazovykh mestorozhdenii v OOO "RN-UfaNIPIneft" [Complex automation of the design of facilities for the development of oil and gas fields in RN-UfaNIPIneft LLC]. Nauchno-tekhnicheskii vestnik $O A O$ “ $N K$ “ROSNEFT"”, 2007, no. 1, pp. 62-66.

36. Makarov E.T. Ispol'zovanie raznorodnoŭ informatsii v sisteme upravleniia proektnymi dannymi Smartplantfoundation [Using heterogeneous information in the project data management system Smartplantfoundation]. CADmaster, 2012, no. 3 (64), pp. 60-63.

37. Vykhodtsev A.V., Kaverin A.A. Kontseptual'noe proektirovanie obustroisstva i dolgosrochnoe planirovanie razrabotki mestorozhdeniia [Conceptual design and long-term planning of oil and gas fields development]. Neftianoe khoziaistvo, 2016, no. 4, pp. 42-45.

38. Koshovkin I.N., Kuzenkov V.Z. Transformatsiia deiatel'nosti neftianykh proektnykh institutov: inzhiniring $\mathrm{i}$ kontseptual'noe proektirovanie [Transformation of the activities of petroleum design institutes: engineering and conceptual design]. Eko, 2012, no. 6, pp. 96-102. DOI: 10.30680/ECO0131-7652-2012-5-96-102

39. Ismagilov R.R., Kudriavtsev I.A., Maksimov Iu.V. Stadiǔnost' kontseptual'nogo proektirovaniia pri razrabotke mestorozhdeniǐ
[Phases of conceptual design for field development]. Neftianoe khoziaistvo, 2014, no. 12, pp. 66-70.

40. Vykhodtsev A.V., Panov R.A. Technology of HighPressure Transport of Multicomponent Hydrocarbon Gases. SPE 163096, 2012. SPE Russian Oil and Gas Exploration and Production Technical Conference and Exhibition, 16-18 October, Moscow, Russia. DOI: 10.2118/163096-RU

41. Guide to the Systems Engineering Body of Knowledge (SEBoK). Versiia 1.9.1, available at: https:// www.sebokwiki.org/ wiki/Guide_to_the_Systems_Engineering_Body_of_Knowledge_(SEBoK) (accessed 07 February 2020).

42. Honour Eric C. Technical report: Value of Systems Engineering. Lean Aerospace Initiative, 2004, October.

43. Introduction to Requirements Engineering. REBOK. Requirements Engineering Body of Knowledge. REQB, 2013.

44. Pennypacker J.S. The Principles of Project Management. New York: PMI, 1997, 232 p.

45. Turner J.R. The Handbook of Project-Based Management. London: McGraw-Hill Companies, 1999, 414 p.

\section{Список литературы}

1. Робастный подход к логистическому инжинирингу на этапах концептуального проектирования / Н.3. Базылева, Р.А. Панов, А.Ф. Можчиль, М.С. Володькин, И.А. Богачев, Н.Д. Шурупов // Нефтяное хозяйство. - 2019. - № 1. - С. 104-108. DOI: $10.24887 / 0028-2448-2019-1-104-108$

2. Власов А.И., Можчиль А.Ф. Обзор технологий: от цифрового к интеллектуальному месторождению // РRОнефть. 2018. - № 3 (9). - С. 68-74.

3. Оптимизация капитальных вложений в строительство скважин при концептуальном проектировании разработки месторождений / В.А. Карсаков, С.В. Третьяков, С.С. Девятьяров, А.Г. Пасынков // Нефтяное хозяйство. - 2013. - № 12. - С. 33-35.

4. Повышение точности оценки капитальных вложений на ранних стадиях реализации проектов / М.М. Хасанов, Д.А. Сугаипов, А.В. Жагрин [и др.] // Нефтяное хозяйство. 2014. - № 12. - С. 22-27.

5. Абрамова Н.С. Неопределенность и риск в инвестиционном проектировании // Экономические науки. 2012. - № 1. - С. 139-144.

6. Борисова Д., Соколов С. Повышение отдачи от крупных инвестиционных проектов // Вестник McKinsey. 2013. - № 28. - С. 6-27.

7. Ансофф И. Стратегический менеджмент. - СПб.: Питер, 2011.

8. Мониторинг стоимости строительства объектов обустройства месторождений на различных стадиях инвестиционного цикла / С.И. Кудряшов, Е.Ю. Белкина, А.Ф. Исмагилов [и др.] // Нефтяное хозяйство. - 2015. - № 11. C. 72-75.

9. Восстание машины. Почему Boeing 737 MAX убивает людей. - 21.03.2019 [Электронный ресурс]. - URL: https://ria.ru/ 20190321/1551968367.html (дата обращения: 10.02.2020).

10. After 2 Crashes of New Boeing Jet, Pilot Training Now a Focus, The New York Times [Электронный pecypc] / N. Kitroeff, D. Gelles, J. Nicas [et al.]. - URL: https://www.nytimes.com/2019/ 03/16/business/boeing-max-flight-simulator-et-hiopia-lion-air.html (дата обращения: 07.02.2020).

11. Hubble_Space_Telescope [Электронный ресурс]. URL: https://www.sebokwiki.org/wiki (дата обращения: 07.02.2020).

12. Батоврин В. Современная системная инженерия и ее роль в управлении проектами (часть 1) // Управление проектами и программами. - 2015. - № 03 (43). - С. 166-178.

13. Системная инженерия. Принципы и практика / А. Косяков, У.Н. Свит, С.Д. Сеймур, С.М. Бимер. - М.: ДМК Пресс, 2014. - 624 с

14. Костенко К., Брезгулевский Е., Мирошниченко Е. Компетенции системного инженера // Молодежь и современные 
информационные технологии: сборник трудов XIII Междунар. науч.-практ. конф. студентов, аспирантов и молодых ученых. Томск, 2016. - 515 с.

15. Портер М. Конкурентное преимущество: как достичь высокого результата и обеспечить его устойчивость. М.: Альпина Бизнес Букс, 2005. - 716 с.

16. Joint optimization of oil well placement and controls / M.C. Bellout, D. Echeverría Ciaurri, L.J. Durlofsky [et al.] // Computational Geosciences. - 2012. - № 16 (4). - P. 1061-1079.

17. Юнусов И.Е. \& Применение ГИС-коннектора для концептуального инжиниринга и стоимостного моделирования обустройства нефтегазовых месторождений // Нефть. Газ. Новации. - 2019. - № 9. - С. 51-53.

18. Стоимостной инжиниринг в ПАО «ГАЗПРОМ НЕФТЬ»: текущая ситуация и перспективы развития / М.М. Хасанов, Ю.В. Максимов, О.О. Скударь [и др.] // Нефтяное хозяйство. - 2015. - № 12. - С. 30-33.

19. Чижиков С.В., Дубовицкая Е.А., Ткаченко М.А. Стоимостное моделирование: инструмент учета изменений // Нефтяное хозяйство. - 2017. - Октябрь. - С. 64-68. DOI: 10.24887/0028-2448-2017-10-64-68

20. Дубовицкая Е.А., Пащенко А.Д., Чижиков С.В. Проблемы оценки затрат на строительство нефтегазовых объектов в России и пути их решения // Нефтяное хозяйство. - 2013. - № 9. - С. 92-95.

21. Бозиева И.А., Зиннатуллин Д.Ф. Аспекты создания корпоративной информационной системы формирования стоимости объектов строительства и обустройства месторождений // Нефтяное хозяйство. - 2016. - № 2. - С. 114-117.

22. Чижиков С.В., Дубовицкая Е.А. Новый подход к оценке и управлению стоимостью нефтегазовых проектов // Нефтяное хозяйство. - 2012. - № 9. - С. 98-101.

23. Опыт реализации базы капитальных вложений по объектам строительства наземной инфраструктуры нефтяных месторождений в ПАО АНК «Башнефть» / А.Р. Атнагулов, Р.Д. Рахмангулов, П.В. Виноградов [и др.] // Нефтяное хозяйство. -2015 . - № 8. - С. 98-101.

24. Выбор стратегии развития региональной инфраструктуры в условиях неопределенности добычи с использованием программного обеспечения «ЭРА:ИСКРА» / Р.Д. Хамидуллин, Р.Р. Исмагилов, А.В. Кан, Ю.В. Максимов, А.Ф. Можчиль, Д.Е. Дмитриев, А.С. Коптелов, Д.Е. Кондаков // Нефтяное хозяйство. - 2017. - № 12. - С. 64-67. DOI: 10.24887/0028-2448-2017-12-64-67

25. Technical Report: Guidance for Decision Quality for Multicompany Up-stream Projects // SPE 181246. - 2016.

26. Интегрированная модель для комплексного управления разработкой и обустройством месторождений / Р.Р. Исмагилов, Ю.В. Максимов, О.С. Ушмаев [и др.] // Нефтяное хозяйство. - 2014. - № 12. - С. 71-73.

27. Экономико-математическое решение для построения оптимальной конфигурации линейных систем нефтегазовых месторождений / Р.Р. Исмагилов, Р.А. Панов, Н.3. Гильмутдинова [и др.] // Нефтяное хозяйство. 2015. - № 12. - С. 60-63.

28. Технико-экономическая оптимизация кустования скважин при интегрированном концептуальном проектировании /
С.В. Третьяков, Д.Е. Дмитриев, Н.3. Гильмутдинова [и др.] // Нефтяное хозяйство. - 2016. - № 04. - С. 126-129.

29. Интегрированное конщептуальное проектирование как инструмент системного инжиниринга / В.П. Батрашкин, Р.Р. Исмагилов, Р.А. Панов [и др.] // Нефтяное хозяйство. 2016. - № 12. - С. 80-83.

30. Алексеев А. Умное ускорение // Сибирская нефть. 2017. - № 6/143. - С. 22-27.

31. Интеграция концептуального логистического инжинринга / Р.Р. Исмагилов, Р.А. Панов, А.Ф. Можчиль, Н.3. Гильмутдинова, Н.Д. Шурупов, И.А. Богачев // РROНефть. 2018. - № 4. - C. 60-63. DOI: 10.24887/2587-7399-2018-4-60-63

32. Amorin R., Broni-Bediako E. Application of minimum curvature method to wellpath calculations // Res. J. Appl. Sci. Eng. and Technol. - 2010. - № 2 (7). - P. 679-686.

33. Fletcher R., Leyffer S. Nonlinear programming without a penalty function // Mathematical Programming. - 2002 . № 91(2). - P. 239-269. DOI: 10.1007/s101070100244

34. Echeverría Ciaurri D., Isebor O.J., Durlofsky L.J. Application of derivative-free methodologies to generally constrained oil production optimisation problems // International Journal of Mathematical Modelling and Numerical Optimisation. 2011. - № 2 (2). - P. 134-161. DOI: 10.1016/j.procs.2010.04.145

35. Комплексная автоматизация проектирования объектов обустройства нефтяных и газовых месторождений в ООО «РН-УфаНИПИнефть / Э.Р. Юмашев, К.Р. Хуснутдинова, А.А. Напольский, А.С. Худин // Научно-технический вестник ОАО «НК «РОСНЕФТЬ». - 2007. - №1. - С. 62-66.

36. Макаров Е.Т. Использование разнородной информации в системе управления проектными данными Smartplantfoundation // CADmaster. - 2012. - № 3 (64). - C. 60-63.

37. Выходцев А.В., Каверин А.А. Концептуальное проектирование обустройства и долгосрочное планирование разработки месторождения // Нефтяное хозяйство. - 2016. № 4. - C. $42-45$.

38. Кошовкин И.Н., Кузенков В.3. Трансформация деятельности нефтяных проектных институтов: инжиниринг и концептуальное проектирование // Эко. - 2012. - № 6. C. 96-102. DOI: 10.30680/ECO0131-7652-2012-5-96-102

39. Исмагилов Р.Р., Кудрявцев И.А., Максимов Ю.В. Стадийность концептуального проектирования при разработке месторождений // Нефтяное хозяйство. - 2014. - № 12. - С. 66-70.

40. Vykhodtsev A.V., Panov R.A. Technology of HighPressure Transport of Multicomponent Hydrocarbon Gases // SPE 163096. - 2012. DOI: $10.2118 / 163096-\mathrm{RU}$

41. Guide to the Systems Engineering Body of Knowledge (SEBoK). Версия 1.9.1 [Электронный ресурc]. - URL: https://www.sebokwiki.org/wiki/Guide_to_the_Systems_Engineeri ng_Body_of_Knowledge_(SEBoK) (дата обращения: 07.02.2020).

42. Honour Eric C. Technical report: Value of Systems Engineering. Lean Aerospace Initiative, 2004. -October.

43. Introduction to Requirements Engineering. REBOK. Requirements Engineering Body of Knowledge. - REQB, 2013.

44. Pennypacker J.S. The Principles of Project Management. - New York: PMI, 1997. - 232 p.

45. Turner J.R. The Handbook of Project-Based Management. - London: McGraw-Hill Companies, 1999. - 414 p.

Please cite this article in English as:

Kelberg K.E., Lyadova N.A. Analysis of Conceptual Engineering Tools Application of in Assets Arrangement System Designing. Perm Journal of Petroleum and Mining Engineering, 2020, vol.20, no.3, pp.253-269. DOI: 10.15593/2712-8008/2020.3.6

Просьба ссылаться на эту статью в русскоязычных источниках следующим образом:

Кельберг К.Э., Лядова Н.А. Анализ применения инструментов концептуального инжиниринга при проектировании системы обустройства активов // Недропользование. - 2020. - Т.20, №3. - С.253-269. DOI: 10.15593/2712-8008/2020.3.6 